\title{
Carcass traits and meat cuts of lambs receiving increasing levels of concentrate ${ }^{1}$
}

\author{
Rendimentos de cortes comerciais e componentes não-carcaça de cordeiros \\ suplementados com doses crescentes de concentrado
}

\author{
Tadeu Vinhas Voltolini*, Salete Alves de Moraes $^{3}$, Gherman Garcia Leal de Araújo ${ }^{3}$, Luiz Gustavo Ribeiro \\ Pereira $^{4}$, Rafael Dantas dos Santos ${ }^{3}$ e André Luiz Alves Neves ${ }^{4}$
}

\begin{abstract}
The use of concentrate for sheep grazing Buffel grass may improve the productive performance and carcass traits of animals. The objective of present trial was to evaluate the productive performance and carcass traits of sheep grazing Buffel grass receiving different concentrate levels. The concentrate levels used were: $0 ; 0.33 ; 0.66$ and $1.0 \%$ of dry matter in relation to body weight. Forty lambs were used, ten animals by treatments, with $16.5 \pm 2.0 \mathrm{~kg}$ of initial body weight and $20.97 \mathrm{~kg}$ final body weight, distributed in four groups. The experimental design was a completely randomized with ten replicates by treatments. The concentrate levels did not influence the cold and hot carcass weight. However, the increasing levels of concentrate promoted higher cold and hot carcass yield. Blood, head, hide, heart, lung, kidney and liver (non carcass components) weights and proportion of slaughtered body weight (SBW) and leg, shoulder, brisket, rib, neck and loin weights (commercial meat cuts) were not affected by increasing levels of concentrate. Full intestine in proportion of SBW was lower with the increase of concentrate levels, while the brisket's weight was higher with increase of concentrate.
\end{abstract}

Key words - Buffel grass. Cenchrus ciliaris. Concentrate supplementation.

\begin{abstract}
Resumo - O uso de concentrados para ovinos mantidos em pastagens de capim-bufel pode melhorar o desempenho produtivo e os parâmetros de carcaça dos mesmos. O objetivo do presente estudo foi avaliar o desempenho produtivo e os parâmetros de carcaça de ovinos mantidos em pastagens de capim-bufel recebendo doses crescentes de suplemento concentrado. As doses de concentrado utilizadas foram: $0 ; 0,33 ; 0,66$ e 1,0\% na matéria seca do suplemento em relação ao peso corporal dos animais. Foram utilizados 40 cordeiros, dez animais por tratamento, com peso corporal inicial médio de 16,5 $\pm 2,0 \mathrm{~kg}$ e peso final de $20,97 \mathrm{~kg}$, distribuídos em quatro grupos. O delineamento experimental adotado foi o inteiramente casualizado. As doses de concentrado não influenciaram o peso de carcaça quente nem fria. Entretanto, o aumento nas doses de concentrado proporcionou maior rendimento de carcaça quente e fria. O peso e a proporção do peso corporal de abate (PCA) de sangue, cabeça, couro, coração, pulmão, rim e fígado (componentes não carcaça) e o peso e proporção da meia carcaça de pernil, paleta, carré, costela, pescoço e lombo (cortes cárneos comerciais) não foram afetados pelo aumento nas doses de concentrado. O intestino cheio em proporção ao PCA foi menor com o aumento de concentrado, enquanto que o peso do carré aumentou com as maiores doses de concentrado.
\end{abstract}

Palavras-chave - Capim-bufel. Cenchrus ciliaris. Suplementação com concentrado.

\footnotetext{
*Autor para correspondência

${ }^{1}$ Recebido para publicação em 13/10/2009; aprovado em 22/03/2011

Pesquisa financiada pelo Banco do Nordeste do Brasil

${ }^{2}$ Embrapa Semiárido, Petrolina-PE, Brasil, tadeu.voltolini@cpatsa.embrapa.br

${ }^{3}$ Embrapa Semiárido, Petrolina-PE, Brasil, salete.moraes@cpatsa.embrapa.br,ggla@cpatsa.embrapa.br, rafael.dantas@cpatsa.embrapa.br

${ }^{4}$ Embrapa Gado de Leite, Juiz de Fora-MG, Brasil, luiz.gustavo@cnpgl.embrapa.br, andre.neves@cnpgl.embrapa.br
} 


\section{Introduction}

The sheep production is one of the most important economic activities of Brazilian semi-arid. However, the production system in this region is characterized as extensive or ultra-extensive, showing low stocking rate of native pastures, low meat and milk yield, low reproductive efficiency of animals and high mortality rate of herds, resulting in a low economic performance to farmers (MOREIRA et al., 2008; VOLTOLINI et al., 2009b).

In this region, there are few alternatives to produce feed to herds especially during dry and rainy transition period of the year. The Buffel grass (Cenchrus ciliaris) is one of them and may be used (GUIMARÃES FILHO; SOARES, 1999; SANTOS et al., 2005). According to Souza and Espíndola (1999) and Souza and Espíndola (2000) the dormant Buffel grass pasture may produce more than $4,500 \mathrm{~kg} /$ year of dry matter.

Nevertheless, this forage may show poor quality, affecting the productive performance of animals (MOREIRA et al., 2007). In addition, the use of concentrate supplementation may increase the productive performance, carcass traits, commercial meat cuts yield and non-carcass components of lambs grazing Buffel grass, especially for animals of high genetic merit (CARVALHO et al., 2007).

The objective of this present study was to evaluate the commercial meat cuts yield and production of non carcass components of lambs grazing Buffel grass receiving increasing levels of concentrate.

\section{Material and methods}

The present trial was carried out at "Campo Experimental da Caatinga" of Embrapa Tropical SemiArid, in Petrolina/PE. Four concentrate levels ( $0 ; 0.33$; 0.66 and $1.0 \%$ of supplement in relation to body weight) were compared. Four hectares of Buffel grass were used, divided in four paddocks of 1.0 ha. Ten lambs were distributed by paddock. In each week the animals were changed of the paddocks.

Forty castrated lambs were used (ten by treatment), with initial body weight of $16.5 \pm 2.0 \mathrm{~kg}$. The experimental design was a completely randomized with ten replicates by treatments.

Petrolina's climate is BSwh' semi-arid, according to Köeppen classification. Climate data registered (air temperatures, relative air humidity, rainfall evapotranspiration and solar radiation) during the experimental period are shown in Table 1.

Soil of area is classified as yellow argisol showing the follow characteristics in the initial phase of experimental trial: $\mathrm{pH}=5.70$; organic matter $=$ $11.17 \mathrm{~g} \mathrm{~kg}^{-1}$; phosphorus $(\mathrm{P})=5 \mathrm{mg} \mathrm{dm}^{-3}$; potassium $(\mathrm{K})=0.36 \mathrm{cmol} \mathrm{dm}^{-3}$; calcium $(\mathrm{Ca})=1.40 \mathrm{cmol}_{\mathrm{c}} \mathrm{dm}^{-3}$; magnesium $(\mathrm{Mg})=0.70 \mathrm{cmol}_{\mathrm{c}} \mathrm{dm}^{-3}$; alluminium $(\mathrm{Al})$ $=0.10 \mathrm{cmol} \mathrm{dm}^{-3}$; hidrogen and alluminium $(\mathrm{H}+\mathrm{Al})=$ $2.97 \mathrm{cmol} \mathrm{dm}^{-3}$; sum of bases $(\mathrm{SB})=2.50 \mathrm{cmol} \mathrm{dm}^{-3}$; cation exchange capacity $(\mathrm{T})=5.47 \mathrm{cmol}_{\mathrm{c}} \mathrm{dm}^{-3}$ and bases saturation $(\mathrm{V})=46 \%$.

Forage mass of pre and post graze (FIG. 1) were estimated using a frame in squared format $\left(1.0 \mathrm{~m}^{2}\right)$. Weekly, two samples of forage were collected in pre and post graze for each paddock, and the cuts were realized in the ground level of soil.

Leaves and stems mass (FIG. 2) were estimated by separation and quantification of dry weight of forage mass components (approximately 100g) in pre and post graze. Samples of entire plant, leaves and stems were weighted in natura and sent to dry matter determinations during 72 hours to $55^{\circ} \mathrm{C}$. Crude protein, ash and in vitro digestibility of dry matter levels were determined according to methodologies describes by Silva and Queiroz (2002) while the levels of neutral detergent fiber and acid detergent fiber were determined according to Van Soest et al. (1991) (FIG. 2).

Table 1 - Climate characteristics registered during experimental period

\begin{tabular}{lcccccccc}
\hline \multirow{2}{*}{ Date } & \multicolumn{3}{c}{ Air temperature $\left({ }^{\circ} \mathrm{C}\right)$} & \multicolumn{2}{c}{ Relative air humidity $(\%)$} & \multirow{2}{*}{ P $(\mathrm{mm})$} & EVP $(\mathrm{mm})$ \\
\cline { 2 - 6 } & Medium & Min. & Max & Medium & Min. & Max. & & 03.99 \\
May & 24.1 & 19.3 & 31.2 & 70.8 & 40.0 & 93.3 & 0 & 3.99 \\
June & 25.2 & 21.1 & 31.2 & 61.3 & 39.6 & 81.8 & 0 & 3.54 \\
July & 23.6 & 17.0 & 30.8 & 59.1 & 31.4 & 92.8 & 0 & 4.85 \\
August & 25.7 & 18.1 & 33.6 & 51.4 & 25.9 & 85.5 & 0 & 5.39 \\
\hline
\end{tabular}

Source: Automatic meteorological station - Campo experimental da Caatinga - Petrolina-PE. Min = minimum, Max $=$ maximum, $\mathrm{P}=$ precipitation, EVP = evapotranspiration 


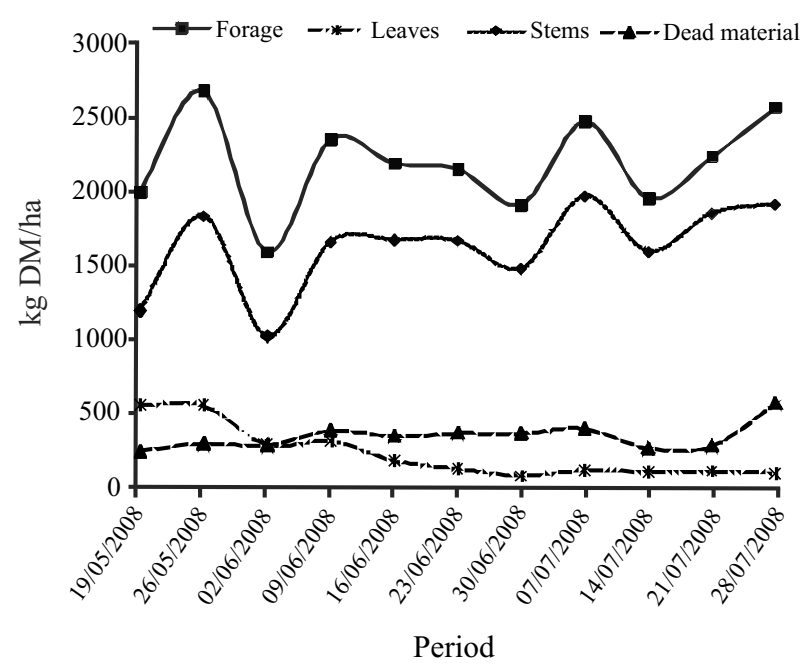

Figure 1 - Forage, leaves, stems and dead material mass of buffel grass grazing by lambs receiving increasing levels of concentrate during the experimental period

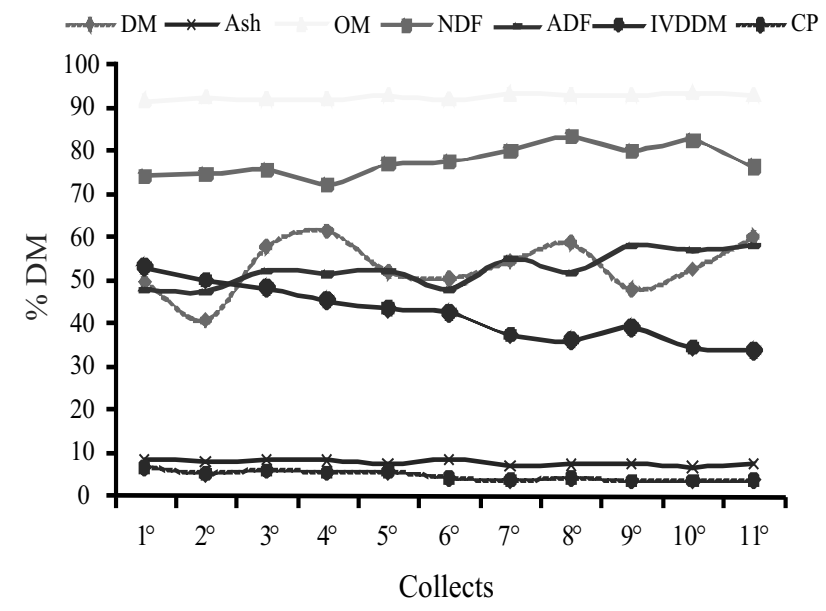

Figure 2 - Chemical composition of buffel grass during experimental period grazed by lambs receiving increasing levels of concentrate

Table 2 - Proportion of ingredients and estimative of crude protein and chemical composition of concentrate

\begin{tabular}{lc}
\hline \multicolumn{1}{c}{ Component } & Concentrate levels (\%) \\
\hline Dry ground corn & 34.0 \\
Wheat bran & 43.0 \\
Soybean meal & 18.0 \\
Urea & 1.0 \\
Mineral e vitamin mix & 4.0 \\
\hline & Chemical composition (\% of dry matter) \\
\hline Dry matter, \% as fed & 90.0 \\
Ash & 7.9 \\
Neutral detergent fiber & 27.7 \\
Acid detergent fiber & 11.1 \\
Crude protein & 20.0 \\
Total digestible nutrients & 75.0 \\
\hline
\end{tabular}

Concentrate was formulated to contain $20 \%$ of crude protein and $75 \%$ of total digestible nutrients (dry matter basis) and offered once a day, at 8:00 hour, in the morning. The amount of supplement was adjusted daily to avoid amount of orts higher than $20 \%$ of the offered. The proportion of ingredients and chemical value of concentrates are showed in Table 2.

Experimental period extended from April to July 2008, during 70 days. Animals were weighted weekly, in the morning. The final body weight (FBW) was the weight obtained in the last weighting. Total weight gain
(TWG) was determined by the follow equation: TWG $=$ FBW - IBW, where IBW = initial body weight. The average daily gain was obtained by division of TWG by the number of days of experimental period. Supplement dry matter intake was calculated by the follow equation: $\mathrm{DMI}=\mathrm{S}-\mathrm{O}$, where DMI = supplement dry matter intake, $\mathrm{S}=$ amount of supplement and $\mathrm{O}=$ amount of orts, in dry matter basis (TAB. 3).

Before the slaughter, the sheep were weighted and kept in fasting of solids for 16 hours. After the slaughter, the carcass were weighted and the carcass yields were calculated 
Table 3 - Supplement intake and productive performance of lambs grazing buffel grass receiving increasing levels of concentrate

\begin{tabular}{|c|c|c|c|c|c|c|}
\hline \multirow{2}{*}{ Component } & \multicolumn{4}{|c|}{ Concentrate levels, $\%$ body weight } & \multirow{2}{*}{$\mathrm{RE}$} & \multirow{2}{*}{$\mathrm{R}^{2}$} \\
\hline & 0 & 0.33 & 0.66 & 1.0 & & \\
\hline Supplement intake, $\mathrm{kg}$ animal $^{-1}$ day $^{-1}$ & 0 & 0.06 & 0.13 & 0.20 & - & - \\
\hline Final body weight, $\mathrm{kg}$ & 21.00 & 19.83 & 21.90 & 21.14 & $\hat{\mathrm{Y}}=20.97$ & 38.15 \\
\hline Average daily gain, $\mathrm{kg}$ & 0.64 & 0.48 & 0.77 & 0.66 & $\hat{\mathrm{Y}}=0.064$ & 38.89 \\
\hline Total weight gain, kg & 4.50 & 3.33 & 5.40 & 4.64 & $\hat{\mathrm{Y}}=4.47$ & 39.17 \\
\hline
\end{tabular}

$\mathrm{RE}=$ Regression of equation; $\mathrm{R}^{2}=$ Coefficient of determination

according the follow equation: $\mathrm{HCD}(\%)=(\mathrm{HCW} / \mathrm{SBW}) \mathrm{x}$ 100 , where $\mathrm{HCY}=$ hot carcass yield, $\mathrm{HCW}=$ hot carcass weight and SBW = slaughtered body weight.

The non carcass components (blood, kidney, head, hide, full intestine, heart, lung and liver) were obtained weighting each component after the slaughter. Each component was also presented as part of half carcass.

The commercial meat cuts was determined using methodologies describe by Cezar and Souza (2007) who cut the half carcass in leg, shoulder, brisket, rib, neck and tenderloin. These data were presented as also in relation to the half carcass.

Statistical analyses were realized by Statistical Analyses System - SAS (1999), using variance analyses and linear regression. Were considered as significant level lower than $5 \%(\mathrm{P}<0.05)$.

Correlation analyses between non carcass components and slaughter body weight (SBW), hot (HCW) and cold carcass weight (CCW) and between the commercial meat cuts with $\mathrm{HCW}$ and $\mathrm{CCW}$ were performed using SAS (1999).

\section{Results and discussion}

The hot and cold carcass weights were not affected $(\mathrm{P}>0.05)$ by the levels of concentrate. On the other hand, the increase of concentrate promoted higher $(\mathrm{P}<0.05)$ hot and cold carcass yield (TAB. 4).
These similar results for the hot and cold carcass weights observed may be justified by the similar final body weight of lambs fed with increasing levels of concentrate.

These results found in the present study are according to Voltolini et al. (2009a) who evaluated the carcass traits of lambs grazing Tifton 85 grass and receiving or not concentrate and they found similar hot carcass weight. Similar results were also reported by Garcia et al. (2003), who evaluated the productive performance and carcass traits of lambs receiving increasing energy levels in creep feed rations.

However, these results are not in accordance with Carvalho et al. (2007) and Souza et al. (2008) who evaluated the carcass traits of lambs grazing tropical pastures and observed higher cold and hot carcass weight with increasing levels of concentrate. In studies proposed by Carvalho et al. (2007) and Souza et al. (2008) the higher carcass weights were justified by higher final body weight of lambs obtained.

In this study, higher cold and hot carcass yield $(\mathrm{P}<0.05)$ with the increasing levels of concentrate were observed. These results suggest that the lambs which received higher levels of concentrate showed higher percentage of carcass yield, probably due to the higher fat levels.

The results for cold and hot carcass yield were low, probably because it was used native breed animals. Voltolini et al. (2009a) evaluated the carcass traits of Santa Ines lambs grazing Tifton 85 grass non supplemented or not with $0.20 \mathrm{~kg} /$ day and they observed $41.94 \%$ of hot carcass weight to non supplemented animals and $43.30 \%$

Table 4 - Hot and cold weights and yield of carcass of sheep grazing Buffel grass pastures receiving increasing levels of concentrate

\begin{tabular}{|c|c|c|c|c|c|c|c|}
\hline \multirow{2}{*}{ Component } & \multicolumn{4}{|c|}{ Concentrate levels } & \multirow[t]{2}{*}{$\mathrm{RE}$} & \multirow[t]{2}{*}{$\mathrm{R}^{2}$} & \multirow[t]{2}{*}{$\mathrm{CV}$} \\
\hline & 0 & 0.33 & 0.66 & 1.0 & & & \\
\hline Hot carcass weight, $\mathrm{kg}$ & 7.75 & 7.57 & 8.46 & 8.22 & $\overline{\mathrm{Y}}=8.22$ & - & 0.11 \\
\hline Cold carcass weight, $\mathrm{kg}$ & 7.42 & 7.28 & 8.15 & 7.93 & $\overline{\mathrm{Y}}=7.93$ & - & 0.13 \\
\hline Hot carcass dressing, $\%$ & 36.84 & 38.06 & 38.64 & 38.86 & $\hat{\mathrm{Y}}=37.11+1.99 \mathrm{C}$ & 0.30 & 0.10 \\
\hline Cold carcass dressing, $\%$ & 35.26 & 36.60 & 37.21 & 34.47 & $\hat{\mathrm{Y}}=35.55+2.18 \mathrm{C}$ & 0.32 & 0.12 \\
\hline
\end{tabular}

$\mathrm{RE}=$ Regression of equation; $\mathrm{R}^{2}=$ Coefficient of determination; $\mathrm{CV}(\%)=$ Coefficient of variation 
to $44.64 \%$ for supplemented animals, in the same region. In addition, Voltolini et al. (2009b) found values of 43.89 to $44.50 \mathrm{~kg}$ for the hot carcass weight to lambs grazing Buffel grass receiving concentrate supplementation in the dry period in Brazilian Northeast semiarid.

The weight and yield of non carcass components (blood, kidney, head, hide, full intestine, heart, lung and liver) were not affected $(\mathrm{P}>0.05)$ by concentrate supplementation. The increase of concentrate promoted $(\mathrm{P}<0.05)$ lower full intestine weight (\% of SBW) (TAB. 5).

In general, the non carcass components weight may be considered low in relation to others studies. Non carcass components (head, hide, heart, liver and kidney), showed by Osorio et al. (1996) who evaluated the meat production of five sheep genotypes grazing native pastures and receiving concentrate supplementation, were 1.05; $2.61 ; 0.12 ; 0.31$ and $0.065 \mathrm{~kg}$, respectively. In proportion of half carcass, the weight obtained by Osorio et al. (1996) was also higher than the results reported in the present study. On the other hand, these same authors obtained higher final body weight of animals resulting in higher non carcass components weights.

Probably, the similar final body weight of lambs promoted the similar weight and yields of non carcass components. The higher weight $(\mathrm{P}<0.05)$ of full intestine correlated with the reduction level of concentrate, may justified by higher amount of forage intake.

The blood, head, hide, full intestine, heart and lung had linear positive correlation between SBW, HCW and $\mathrm{CCW}$ (TAB. 4), showing that bigger animals or carcass promoted an increase of non carcass components. The kidney weight was not affected $(\mathrm{P}<0.05)$ by SBW, HCW or CCW.

The commercial meat cuts weights and yields (leg, shoulder, rib, brisket, neck and loin) were not affected $(\mathrm{P}>0.05)$ by concentrate levels used (TAB. 5). These results can be justified by absence of significant response of concentrate levels on carcass weight and yield.

Gonzaga Neto et al. (2006) evaluated the inclusion of concentrate in rations to lambs in feedlot and they found higher pallete (shoulder), leg, loin, rib and neck weights using increasing levels of supplement in function of higher average daily gain and final body weight of lambs. In this study Gonzaga Neto et al. (2006) observed 0.82; $1.40 ; 0.50 ; 1.04$ and $0.41 \mathrm{~kg}$ of shoulder, leg, loin, rib and neck weight, respectively. On the other hand, the weight of shoulder, leg, loin, rib and neck obtained in the present study were $0.65 ; 1.23 ; 0.29 ; 0.96$ and $0.39 \mathrm{~kg}$, lower than the results reported by Gonzaga Neto et al. (2006) with similar half carcass weight.

Table 5 - Weight and yields non carcass components of sheep grazing Buffel receiving increasing levels of concentrate

\begin{tabular}{|c|c|c|c|c|c|c|}
\hline \multirow{2}{*}{ Components } & \multicolumn{4}{|c|}{ Concentrate levels ( $\%$ of dry matter) } & \multirow{2}{*}{$\mathrm{RE}$} & \multirow{2}{*}{$\mathrm{R}^{2}$} \\
\hline & 0 & 0.33 & 0.66 & 1 & & \\
\hline Blood, kg & 0.69 & 0.65 & 0.69 & 0.75 & $\overline{\mathrm{Y}}=0.69$ & - \\
\hline Blood, $\%$ of SBW & 3.26 & 3.26 & 3.12 & 3.54 & $\overline{\mathrm{Y}}=3.30$ & - \\
\hline Kidney, $\mathrm{kg}$ & 0.06 & 0.06 & 0.06 & 0.06 & $\bar{Y}=0.06$ & - \\
\hline Kidney $\%$ of SBW & 0.30 & 0.30 & 0.24 & 0.30 & $\bar{Y}=0.26$ & - \\
\hline Head, $\mathrm{kg}$ & 0.93 & 0.91 & 0.96 & 0.95 & $\bar{Y}=0.94$ & - \\
\hline Head, $\%$ of SBW & 4.43 & 4.57 & 4.39 & 4.47 & $\bar{Y}=4.46$ & - \\
\hline Hide, $\mathrm{kg}$ & 1.63 & 1.50 & 1.79 & 1.55 & $\overline{\mathrm{Y}}=1.61$ & - \\
\hline Hide, $\%$ of SBW & 7.75 & 7.53 & 8.13 & 7.35 & $\bar{Y}=7.69$ & - \\
\hline Full intestine, kg & 7.48 & 6.84 & 7.02 & 6.77 & $\bar{Y}=7.03$ & \\
\hline Full intestine, $\%$ of SBW & 35.61 & 34.62 & 32.02 & 32.18 & $\hat{\mathrm{Y}}=35.54+3.92 \mathrm{C}$ & 0.24 \\
\hline Heart, kg & 0.09 & 0.09 & 0.10 & 0.09 & $\overline{\mathrm{Y}}=0.09$ & - \\
\hline Heart, $\%$ of SBW & 4.43 & 4.57 & 4.39 & 4.47 & $\bar{Y}=4.46$ & - \\
\hline Lung, kg & 0.18 & 0.17 & 0.19 & 0.20 & $\bar{Y}=0.19$ & - \\
\hline Lung, $\%$ of SBW & 0.86 & 0.85 & 0.88 & 0.94 & $\bar{Y}=0.88$ & - \\
\hline Liver, $\mathrm{kg}$ & 0.25 & 0.24 & 0.25 & 0.27 & $\bar{Y}=0.25$ & - \\
\hline Liver, $\%$ of SBW & 1.19 & 1.18 & 1.13 & 1.28 & $\overline{\mathrm{Y}}=1.20$ & - \\
\hline
\end{tabular}

$\mathrm{C}=$ Concentrate level; $\mathrm{RE}=$ Regression of equation; $\mathrm{R}^{2}=$ Coefficient of determination 
Table 6 - Pearson correlation coefficient between non carcass components and slaughter body weight, hot and cold carcass weight of lambs grazing Buffel grass and receiving increasing levels of concentrate

\begin{tabular}{llll}
\hline \multicolumn{1}{c}{ Item } & SBW & HCW & CCW \\
\hline Blood & $0.72^{* *}$ & $0.73^{* *}$ & $0.73^{* *}$ \\
Kidney & 0.09 & 0.04 & 0.09 \\
Head & $0.81^{* *}$ & $0.76^{* *}$ & $0.76^{* *}$ \\
Hide & $0.63^{* *}$ & $0.58^{* *}$ & $0.58^{* *}$ \\
Full intestine & $0.49^{* *}$ & $0.50^{* *}$ & $0.49^{* *}$ \\
Heart & $0.45^{* *}$ & $0.35^{*}$ & $0.35^{*}$ \\
Lung & $0.60^{* *}$ & $0.47^{* *}$ & $0.47^{* *}$ \\
\hline
\end{tabular}

$* \mathrm{P}<0.05 ; * * \mathrm{P}<0.01$. SBW $=$ slaughtered body weight, $\mathrm{HCW}=$ hot carcass weight, $\mathrm{CCW}=$ cold carcass weight

Table 7 - Weight and yield of commercial meat cuts of sheep grazing Buffel grass pastures receiving multiple supplementation containing increasing levels of concentrate

\begin{tabular}{|c|c|c|c|c|c|c|}
\hline \multirow{2}{*}{ Component } & \multicolumn{4}{|c|}{ Concentrate levels ( $\%$ of dry matter) } & \multirow[t]{2}{*}{ RE } & \multirow[t]{2}{*}{$\mathrm{R}^{2}$} \\
\hline & 0 & 0.33 & 0.66 & 1 & & \\
\hline Leg, kg & 1.20 & 1.17 & 1.30 & 1.24 & $\overline{\mathrm{Y}}=1.23$ & - \\
\hline Leg, $\%$ of half carcass & 30.47 & 32.02 & 35.95 & 31.32 & $\overline{\mathrm{Y}}=32.00$ & - \\
\hline Shoulder, kg & 0.65 & 0.63 & 0.61 & 0.66 & $\bar{Y}=0.65$ & - \\
\hline Shoulder, $\%$ of half carcass & 16.45 & 17.18 & 18.71 & 16.57 & $\bar{Y}=17.23$ & - \\
\hline Brisket, $\mathrm{kg}$ & 0.59 & 0.60 & 0.69 & 0.66 & $\hat{\mathrm{Y}}=0.59+0.09 \mathrm{C}$ & 0.11 \\
\hline Brisket, $\%$ of half carcass & 15.05 & 16.60 & 18.88 & 16.71 & $\overline{\mathrm{Y}}=16.81$ & - \\
\hline Rib, kg & 0.91 & 0.92 & 1.03 & 0.99 & $\overline{\mathrm{Y}}=0.96$ & - \\
\hline Rib, $\%$ of half carcass & 23.23 & 23.25 & 28.42 & 25.02 & $\overline{\mathrm{Y}}=25.48$ & - \\
\hline Neck, kg & 0.38 & 0.37 & 0.40 & 0.41 & $\bar{Y}=0.39$ & - \\
\hline Neck, $\%$ of half carcass & 9.77 & 10.16 & 10.97 & 16.71 & $\overline{\mathrm{Y}}=16.81$ & - \\
\hline Loin, kg & 0.28 & 0.26 & 0.31 & 0.31 & $\overline{\mathrm{Y}}=0.29$ & - \\
\hline Loin, $\%$ of half carcass & 4.05 & 3.71 & 3.66 & 3.97 & $\bar{Y}=36.85$ & - \\
\hline
\end{tabular}

$\mathrm{RE}=$ Regression of equation; $\mathrm{C}=$ concentrate level; $\mathrm{R}^{2}=$ Coefficient of determination

Clementino et al. (2007) evaluated the productive performance and carcass traits of lambs receiving increasing levels of concentrate and they observed higher neck, shoulder, rib, loin and neck weights due to the greater levels of concentrate. They justified these results by higher average daily gain and final body weight of animals receiving greater concentrate levels.

Gonzaga Neto et al. (2006) did not observe increase in leg, shoulder, rib and neck weight in proportion of half carcass using greater concentrate levels, however the loin weight (\% of half carcass) increased with higher levels of concentrate, representing the anatomical harmony of carcass.

Clementino et al. (2007) also observed similar loin weight (\% of half carcass), but found higher shoulder, leg, rib and neck weight ( $\%$ of half carcass) using greater levels of concentrate to fed lambs, justified these results by early development of these meat cuts.

In this study, brisket's weight increased with higher levels of concentrate $(\mathrm{P}<0.05)$ probably due to carcass weight. Using $0 ; 0.33 ; 0.66$ and $1 \%$ of supplement in relation of body weight of animals showed $7.42 ; 7.28$; 8.15 and $7.93 \mathrm{~kg}$ of cold carcass weight, respectively and this, consequently, may be occasioned with the increase in brisket's weight, probably this meat's cut may be more sensible in relation to use of concentrate.

The leg was the heaviest commercial meat cut of lamb observed in present trial. It represented more than $30 \%$ of half carcass. The leg's weight was similar to those 
found by Menezes et al. (2008) who evaluated the carcass traits and commercial meat cuts of Santa Ines grazing Andropogon grass (Andropogon gayanus cv. Planaltina), Tanzania grass (Panicum maximum cv. Tanzania) and Aruana grass (Panicum maximum cv. Aruana) receiving concentrate with $21.7 \%$ of protein during dry season and they related leg's weight of $1.30 \mathrm{~kg}$ using animals with similar slaughtered body weight.

In this study, the leg's yields were higher than reported by Menezes et al. (2008) which showed values of $28.4 \%$ to $29.9 \%$. Probably, the different animal genotype used promoted these differences in leg's weight. However, Cunha et al. (2008) evaluated the responses to increasing levels of whole cottonseed on the carcass traits and commercial meat cuts of feedlot Santa Ines and they observed leg's yield of $30.81 \%$ to $32.16 \%$ of half carcass using animals weighting more than $30 \mathrm{~kg}$ of body weight. This fact suggests that the production system (feedlot $\mathrm{x}$ pasture), age, physiological status or slaughtered body weight have great influence on weight and consequently on weight of commercial meat cuts weights.

No significant correlation $(\mathrm{P}>0.05)$ was observed between commercial meat cuts weights and HCW or CCW.

In this study, the shoulder and rib's weight and yields were lower than reported by Menezes et al. (2008) who obtained values from 1.162 to $1.472 \mathrm{~kg} ; 0.453$ to $0.627 \mathrm{~kg}$ and $9.40 \%$ to $10.8 \%$ of half carcass; $23.0 \%$ to $25.2 \%$ of half carcass for shoulder and rib, respectively. In Menezes et al. (2008)'s study, the standards cuts of meats were different compared with the present trial, contributing for the differences observed in weight and shoulder and rib's yield. Brisket's weight and yields were not evaluated by Menezes et al. (2008). Using similar standards meat cuts, but working with more weighted animals (30.41 to $33.50 \mathrm{~kg}$ of body weight), Cunha et al. (2008) found that the weight of shoulder varied from 1.34 to $1.53 \mathrm{~kg}$, representing 19.3 to $21.7 \%$, while the weight varied from 0.847 to $0.910 \mathrm{~kg}$, corresponding to 11.54 to $12.43 \%$ of half carcass, indicating that the standards of meat cuts may explain the results found.

Oliveira et al. (2002) evaluated the carcass traits and commercial meat cuts of feedlot Santa Ines and Brazilian Bergamacia sheep receiving swine dry siltest wastes and they related brisket's weight of 1.82 and 2.02 $\mathrm{kg}$ to Santa Ines and Brazilian Bergamacia, respectively. These weights are higher than found in the present study, but the animals used by Oliveira et al. (2002) showed more than $40 \mathrm{~kg}$ of slaughtered body weight.

\section{Conclusions}

1.The use of increasing levels of concentrate did not affect the hot and cold carcass weight, but promoted better hot and cold carcass yield;

2.The most of non carcass components and commercial meat cuts yields were not affected by increasing levels of concentrate;

3.Full intestine's weight decreased with increase of concentrate, while brisket's weight was higher with increase of concentrate.

\section{References}

CARVALHO, S. et al. Desempenho e características da carcaça de cordeiros mantidos em pastagens de Tifton 85 e suplementados com diferentes níveis de concentrado. Revista Brasileira de Agrociência, v. 12, n. 03, p. 357-361, 2007.

CEZAR, M. F.; SOUZA, W. H. de. Carcaças ovinas e caprinas: obtenção, avaliação e classificação. Uberaba, MG: Agropecuária Tropical, 2007. 147 p.

CLEMENTINO, R. H. et al. Influência dos níveis de concentrado sobre os cortes comerciais, os constituintes não carcaça e os componentes da perna de cordeiros confinados. Revista Brasileira de Zootecnia, v. 36, n. 03, p. 681-688, 2007.

CUNHA, M. das G. G. et al. Características quantitativas de carcaça de ovinos Santa Inês confinados alimentados com rações contendo diferentes níveis de caroço de algodão integral. Revista Brasileira de Zootecnia, v. 37, n. 06, p. 1112-1120, 2008.

GARCIA, C. A. et al. Níveis de energia no desempenho e características da carcaça de cordeiros alimentados em creep-feeding. Revista Brasileira de Zootecnia, v. 32, n. 06, p. 1371-1379, 2003.

GONZAGA NETO, S. et al. Características quantitativas da carcaça de cordeiros deslanados Morada Nova em função da rela;cão de volumoso e concentrado na dieta. Revista Brasileira de Zootecnia, v. 35, n. 04, p. 1487-1495, 2006.

GUIMARÃES FILHO, C.; SOARES, J. G. G. Avaliação de um modelo físico de produção de bovinos no semi-árido integrando Caatinga, Buffel e Leucena. I. Fase de cria. Pesquisa Agropecuária Brasileira, v. 34, n. 09, p. 17211727, 1999.

MENEZES, L. F. de. O. et al. Características de carcaça, componentes não carcaça e composição tecidual e química da $12^{\text {a }}$ costela de cordeiros Santa Inês terminados em pasto com três gramíneas no período seco. Revista Brasileira de Zootecnia, v. 37, n. 07, p. 1286-1292, 2008.

MOREIRA, J. N. et al. Potencial de produção de capim Buffel na época seca no semi-árido Pernambucano. Revista Caatinga, v. 20, n. 03, p. 22-29, 2007. 
MOREIRA, J. N. et al. Alternativas de volumosos para caprinos em crescimento. Revista Brasileira de Saúde e Produção Animal, v. 09, n. 03, p. 407- 415, 2008.

OLIVEIRA, M. V. M. de. et al. Rendimentos de carcaça, mensurações e peso de cortes comerciais, de cordeiros Santa Inês e Bergamácia, alimentados com dejetos de suínos em confinamento. Revista Brasileira de Zootecnia, v. 31, n. 03, p. 1451-1458, 2002. Suplemento.

OSORIO, J. C. et al. Produção de carne em ovinos de cinco genótipos: 2. Componentes do peso vivo. Ciência rural, v. 26, n. 03, p. 471-475, 1996.

SANTOS, G. R. de A. et al. Caracterização do pasto de capim Buffel diferido e da dieta de bovinos durante o período seco no sertão de Pernambuco. Revista Brasileira de Zootecnia, v. 34, n. 02, p. 454-463, 2005.

SILVA, D. J.; QUEIROZ, A. C. de. Análise de Alimentos: métodos químicos e biológicos. 3.ed, Viçosa: UFV, 2002. 235p.

SAS INSTITUTE. SAS STAT user's guide: version 6.4 . Cary, 1999.
SOUZA, A. A. de.; ESPÍNDOLA, G. B. Efeito da suplementação com feno de leucena (Leucaena leucocephala (Larn)de Wit) durante a estação seca sobre o desenvolvimento ponderal de ovinos. Revista Brasileira de Zootecnia, v. 28, n. 06, p. 1424-1429, 1999.

SOUZA, A. A. de.; ESPÍNDOLA, G. B. Bancos de proteína de leucena e de guandú para suplementação de ovinos mantidos em pastagem de capim Buffel. Revista Brasileira de Zootecnia, v. 29 , n. 02 , p. $365-372,2000$.

SOUZA, R. A. et al. Desempenho produtivo de ovinos mantidos em pastagem de Tifton 85 recebendo doses crescentes de suplementação com concentrado In: CONGRESSO NORDESTINO DE PRODUÇÃO ANIMAL, 5., 2008, Aracajú. Anais... Aracajú/SE, 2008. 1 CD-ROM.

VOLTOLINI, T. V. et al. Alimentos energéticos em rações para caprinos em crescimento. Revista Brasileira de Saúde e Produção Animal, v. 10, n. 02, p. 302-310, 2009a.

VOLTOLINI, T. V.; ARAÚJO, G. G. L.de.; MORAES, S. A. Urea levels in multiple supplement for grazing sheep. Acta Scientiarum - Animal Sciences, 2009b. In press. 